\title{
Reducción de daños en embarazos no deseados y de adicciones no deseadas: una instructiva analogía
}

\section{Harm-reduction for unwanted pregnancies and unwanted addictions: an instructive analogy}

\author{
Colin Brewer \\ Research Director. The Stapleford Centre. London \\ Enviar correspondencia a:
}

Colin Brewer. Director de Investigación. The Stapleford Centre. London. SW1W 9NP. Reino Unido. E-mail: cbrewer@doctors.net.uk.

\section{RESUMEN}

El tratamiento de las adicciones busca reducir el daño que la adicción causa a los individuos y a la sociedad. Sin embargo, muchos servicios, sobre todo en el sector privado, tienen objeciones ideológicas a la hora de utilizar tratamientos médico-farmacológicos y se muestran críticos con otros servicios que sí ofrecen tratamientos farmacológicos. Esta situación contrasta profundamente con la actitud de las clínicas de planificación familiar (PF), que también buscan reducir daños. Irónicamente, las clínicas más antifarmacológicas suelen ser las que proclaman a toda voz que la adicción es una "enfermedad», mientras que el evitar un embarazo no deseado, que no se considera enfermedad, se aborda y soluciona de forma muy efectiva con técnicas médicas. Las clínicas de PF tienen en cuenta los diferentes modelos de conducta sexual, los contextos sociales y las actitudes de las pacientes cuando diseñan planes de tratamiento individuales, mientras que las clínicas que tratan adicciones parten de un enfoque de talla única o de "lo tomas o lo dejas". Los servicios de adicción pueden aprender lecciones clínicas e ideológicas muy útiles de las clínicas de PF.

Palabras clave: adicción, alcohol, contracepción, reducción del daño, heroína, embarazo, naltrexona.

\section{ABSTRACT}

Addiction treatment aims to reduce the harm that addiction causes to individuals and society. However, many clinics, especially in the private sector, have ideological objections to using medico-pharmacological treatments and are often critical of other services that do offer pharmacological treatments. This situation contrasts sharply with the attitude of family planning (FP) clinics, even though they too aim to reduce harm. Ironically, the most anti-pharmacological clinics are often those which proclaim most loudly that addiction is a 'disease', while avoiding unwanted pregnancy, which is not usually seen as a disease, is widely and effectively achieved with medical techniques. FP clinics typically consider widely varying patterns of sexual behaviour, social contexts and patient attitudes in devising individual treatment plans, while addiction clinics commonly have a one-size-fits-all, take-it-orleave-it approach. Addiction services could learn some useful clinical and ideological lessons from FP clinics.

Key words: addiction, alcohol, contraception, harm-reduction, heroin, pregnancy, naltrexone.

\section{INTRODUCCIÓN}

A I margen de las definiciones, las adicciones problemáticas presentan modelos repetidos de conducta, con sus reiteradas consecuencias negativas (generalmente no deseadas). Cuando se abordan las adicciones farmacológicas, el ideal es lograr la abstinencia y la no dependencia psicológica y física; sin embargo, los médicos suelen contentarse con reducir de forma significativa los daños que la adicción causa a los individuos y a la sociedad durante períodos significativos, aunque persistan o se repitan ciertas conductas adictivas. Es lo que denominamos

\section{INTRODUCTION}

$\mathbf{H}$ owever we define them, troublesome addictions involve repeated patterns of behaviour and their repeated (and usually undesired) harmful consequences. In managing pharmacological addictions, achieving abstinence and freedom from psychological and physical dependence remains the ideal but clinicians are often satisfied with significantly reducing the amount of harm that the addiction causes to individuals and to society for useful periods, even if some addictive behaviour persists or recurs. That is what we mean by 'harm reduction' 
«reducción del daño» (RD). En este artículo examinaré en detalle un tipo de RD que tal vez en un principio se considere poco relevante en relación con el tratamiento de las adicciones, pero que a mi modo de ver proporciona analogías útiles ${ }^{1}$. La RD en cuestión se denomina "contracepción» o "planificación familiar» (PF) y está muy extendida porque son muchas las personas que desean evitar un tipo concreto de daño, el embarazo no deseado, que es una consecuencia generalmente desagradable de las relaciones sexuales.

\section{Reducción del daño en el control de las adicciones}

Existen grandes divergencias entre las personas que tratan a los consumidores de sustancias: por un lado están los que piensan que hay lugar para los tratamientos farmacológicos, y por otro los que opinan que no hay lugar para ellos. La discusión es muy tendenciosa, porque los defensores del tratamiento farmacológico aceptan también el tratamiento psicosocial. Por el contrario, amplios sectores del mundo que trata las adicciones, sobre todo las unidades residenciales, se oponen de tal forma al tratamiento farmacológico que no admiten a los pacientes que toman medicación para la reducción de daños o para la prevención de recaídas. En estos establecimientos la labor de los médicos, aparte de tratar afecciones médicas o quirúrgicas concurrentes, se limita a ayudar a los pacientes a prescindir por completo de las drogas ilegales o de mantenimiento para emprender el "verdadero» trabajo de renacimiento espiritual, moral y social. A veces incluso se rechazan por motivos ideológicos drogas psicotrópicas con escaso potencial de dependencia, como el litio o los antidepresivos.

La eficacia de los establecimientos residenciales no es tanta como para ignorar la farmacología. El clásico ensayo controlado aleatorio (RCT) de tratamiento de pacientes externos con mantenimiento de metadona (TMM) frente a las comunidades terapéuticas (CT) demostró que eran muchos más los que aceptaban el TMM que los que optaban por las $\mathrm{CT}^{2}$. Y sobre todo, mientras las CT perdían aproximadamente al 80\% de los residentes al cabo de seis meses, la tasa de retención de los TMM a los doce meses era del 74.5\%. Se observaron resultados similares en un reciente estudio británico ${ }^{3}$, que descubrió «bajos niveles globales de finalización del programa y niveles elevados de abandono y expulsión no planeada del programa». Sólo el 25\% de los residentes permanecieron más de 90 días y sólo un $13 \%$ se calificaron como "éxitos».

Si las clínicas residenciales aceptasen pacientes de TMM o les ofreciesen una alternativa a la desintoxicación obligatoria, seguramente esas cifras tan bajas mejorarían. EI TMM puede actuar como un poderoso incentivo para la permanencia, lo cual permite a los pacientes beneficiarse del ambiente terapéutico y de
(HR). In this paper, I will examine in some detail a type of HR that may seem at first to have little relevance to addiction treatment but which I believe provides some useful analogies'. The HR in question is usually called 'contraception' or 'family planning' (FP) and is widely used because many people want to avoid a specific type of harm, namely unwanted pregnancy, which is a common undesired consequence of sexual behaviour.

\section{Harm-reduction in addiction control}

There is a fundamental disagreement among people who treat substance-abusers between those who think there is a place for pharmacological treatments and those who think there is no place for them at all. The argument is entirely one-sided because supporters of pharmacological treatment readily accept that there is a place for psychosocial treatment components as well. In contrast, large areas of the addiction treatment world, especially residential units, are so opposed to pharmacological treatment that they will not accept patients for treatment if they are taking any harm-reduction or relapse-prevention medication at all. If such establishments employ doctors, other than for treating concurrent medical or surgical conditions, it is only to assist patients to withdraw completely from illicit or maintenance drugs, so that the 'real' work of spiritual, moral and social renaissance may begin. Even psychotropic drugs with little dependence-inducing potential, such as lithium or anti-depressants, may be ideologically unacceptable.

Residential establishments are not so effective that they can ignore pharmacology. The classic Randomised Controlled Trial (RCT) of out-patient Methadone Maintenance Treatment (MMT) vs Therapeutic Communities (TCS) found that significantly more patients accepted MMT than TCs ${ }^{2}$. More importantly, while TCs lost over $80 \%$ of their residents after six months, the 12-month MMT retention-rate was $74.5 \%$. Similar results characterised a recent British study ${ }^{3}$, which found 'overall low levels of programme completion and high levels of unplanned programme departure and eviction'. Only $25 \%$ of residents stayed for more than 90 days: only $13 \%$ were defined as 'successes'.

If residential clinics accepted patients on MMT or offered it to them as an alternative to compulsory detoxification, it is likely that these depressing figures would improve. MMT could be a powerful inducement to stay and thus to benefit from the potentially therapeutic atmosphere and structure of a good resi- 
la estructura de una buena clínica residencial. Cuando los residentes consiguen dominar o recuperar las habilidades sociales, psicológicas y laborales, son dados de alta continuando con el TMM, o dejan los opiáceos con o sin la protección de naltrexona en inyección depot o supervisada por vía oral. De forma similar, los alcohólicos reincidentes que tienen dificultades para dejar de consumir alcohol incluso en el ambiente favorable de un centro de rehabilitación, se beneficiarían de la estancia en un centro siempre que se les administrase disulfiram bajo supervisión para asegurar su adhesión; opción mucho mejor que la expulsión, que es lo que ocurre habitualmente. Sin duda, sería una forma razonable y basada en la evidencia de sumar los beneficios ${ }^{4,}$ ${ }^{5}$ de los componentes farmacológicos del tratamiento a los psicosociales, y resultaría especialmente útil para un grupo de pacientes cuyos problemas son por definición muy graves. Expulsar a los pacientes de una clínica porque continúan con la conducta que los llevó a ingresar en la misma es como expulsar a los esquizofrénicos de los hospitales psiquiátricos porque continúan sufriendo alucinaciones. Sin embargo, sólo conozco dos centros residenciales de rehabilitación en Inglaterra que, tras muchos aspavientos ideológicos, admiten pacientes que toman naltrexona o disulfiram e incluso a unos pocos en tratamiento TMM.

El TMM provoca objeciones morales concretas en ciertos ambientes aparte de las objeciones derivadas del rechazo general a las intervenciones médicas. Si bien el tratamiento con naltrexona (NTX) es el polo opuesto desde el punto de vista farmacológico y psicológico al TMM, muchos países muestran poco interés en el mismo, siendo España una de las escasas excepciones. Los implantes o inyecciones depot eliminan en gran parte los problemas de conformidad que minaban la efectividad potencial de la NTX oral, pero el pequeño número de estudios controlados que han examinado la naltrexona oral administrada como requisito de la libertad condicional hallaron beneficios muy significativos cuya duración era de un año o más ${ }^{6,7}$. Sin embargo, estos programas son aún muy raros.

\section{Reducción del daño en las clínicas de planificación familiar}

Gran parte de las técnicas más efectivas para evitar los embarazos no deseados fueron desarrolladas por médicos y farmacéuticos. (No analizaré la interrupción del embarazo en este artículo, pues no siempre indica un error contraceptivo $\left.{ }^{8}\right)$. La contracepción tiene enemigos, aunque nunca he visto que nadie se oponga a que se utilicen métodos médicos para evitar el embarazo con el pretexto de que el embarazo no deseado no es una enfermedad. Ciertos grupos religiosos rechazan los métodos médicos y otros, pero incluso los creyentes más firmes prescinden de las objeciones, tanto los usuarios como los proveedores dential clinic. Once they had mastered or rediscovered useful social, psychological and employment skills, residents could be discharged on continued MMT, or opiate-free with or without the protection of depot or supervised oral naltrexone. Similarly, relapsing alcoholics who found it difficult to stop using alcohol, even in the supportive atmosphere of a rehabilitation centre, could be encouraged to stay and benefit, provided they took disulfiram under supervision to demonstrate their commitment, rather than being expelled, which is what nearly always happens. Surely this would be a sensible and evidence-based way of adding the benefits ${ }^{4,5}$ of pharmacological components of treatment to those of psycho-social ones and might be particularly helpful for a group of patients whose problems are often, by definition, very severe? To expel patients from a clinic because they continue to do what brought them into the clinic in the first place is like expelling schizophrenics from psychiatric hospitals because they continue to hallucinate. Yet I know of only two residential rehabilitation centres in Britain which, after much ideological hand-wringing, will admit patients taking naltrexone or disulfiram and even fewer that will take patients on MMT.

MMT generates specific moral objections in some quarters in addition to objections based on a general dislike of medical interventions. Yet even if we consider treatment with NTX, pharmacologically and psychologically the polar opposite of MMT, we find little enthusiasm for it in many countries, Spain being one of the few exceptions. Implants or depot injections largely eliminate the problems of compliance that undermined the potential effectiveness of oral NTX but the small number of controlled studies that have examined oral naltrexone given as a condition of probation found very significant benefits lasting a year or more. ${ }^{6,7}$ However, such programmes are still rare.

\section{Harm-reduction in the family planning clinic}

Many of the most effective techniques for preventing unwanted pregnancy were developed by doctors and pharmacologists. (I shall not discuss termination of pregnancy here but it does not usually reflect contraceptive failure. ${ }^{8}$ ) Contraception has its enemies but I have never heard anybody argue against using medical methods for avoiding pregnancy on the grounds that unwanted pregnancy is not a disease. Some religious groups object to medical and other methods but even among active believers, the objections are widely disregarded by both users and providers of FP services. Abstinence, in or out of marriage, has long 
de servicios de PF. La mayoría de la gente considera la abstinencia dentro o fuera del matrimonio una técnica de RD poco realista.

Conociendo la naturaleza humana, no todos los que admiten que se deben tomar precauciones contra los embarazos no deseados actúan con diligencia. Numerosos estudios demuestran que, a pesar del fácil acceso a los métodos contraceptivos, los individuos y las parejas mantienen relaciones sexuales sin protección (sobre todo los jóvenes) debido a las tentaciones del sexo y al rechazo a supeditar el triunfo del placer a la voz interior que les advierte de las nefastas consecuencias $^{9}$. Problemas similares afectan a las personas que consumen repetidamente alcohol y otras drogas a pesar de conocer los riesgos que entrañan. Como en el caso anterior, la juventud es un destacado factor de riesgo añadido. Es más, muchos embarazos no deseados se producen porque uno o los dos miembros de la pareja están demasiado ebrios para atender a su voz interior.

Tanto los médicos de PF como la industria farmacéutica han reconocido esos desordenados aspectos de la vida reproductiva y, en consecuencia, han diseñado técnicas apropiadas y fáciles de utilizar para los que tienen dificultades, por las razones que sean, en usar métodos que requieren planificación, organización y previsión, como la píldora, o una leve disminución del placer, como los métodos barrera. Primero, surgió el dispositivo contraceptivo intrauterino; luego, las inyecciones de progesterona de efecto prolongado o varias soluciones para el "día después». Para quienes no desean tener más hijos, existen diversas técnicas de esterilización femenina o masculina.

En las clínicas de PF hay pacientes que rechazan estos métodos médico-quirúrgicos. Aparte del número relativamente reducido de personas con fuertes creencias religiosas contrarias a cualquier tipo de control de la fertilidad o a separar los aspectos placenteros y procreadores del sexo, hay muchas personas no religiosas que no quieren que los médicos les alteren las hormonas o les coloquen dispositivos de plástico en el útero. Otras no desean someterse al ligamento de las trompas de Falopio o de los conductos espermáticos. A estas personas se dirigen los métodos de $\mathrm{RD}$ basados en una mejor compresión de las fases fértiles e infértiles del ciclo menstrual.

En las clínicas de PF habituales todos estos métodos coexisten de forma pacífica. La labor del personal consiste en mostrar y, en caso necesario, explicar el menú terapéutico y en ayudar a los pacientes a efectuar una elección informada, aunque los pacientes suelen tener una idea bien sólida del método de RD que mejor encaja con sus necesidades y no tardan mucho en elegir. Aunque los especialistas en PF crean que la opción del paciente no es ideal, no acostumbran a oponerse a ella a menos que existan claras contrain- been generally recognised as an unrealistic HR technique for most people.

Human nature being what it is, not everyone who recognises that they ought to be taking precautions against unwanted pregnancy always does so diligently. Numerous studies show that despite easy access to effective contraceptive methods, individuals and couples often have sex without protection (particularly when they are young) because the temptations of sex and the reluctance to delay gratification triumph over the inner voice warning them that it will end in tears. ${ }^{9}$ Very similar problems affect people who repeatedly use alcohol or other drugs unwisely despite knowing the risks involved. Again, youth is a prominent additional risk factor. Indeed, many unwelcome pregnancies happen because one or both sexual partners were too intoxicated to heed that voice.

Both FP doctors and the pharmaceutical industry have long recognised these untidy facts of reproductive life and have therefore devised appropriate, userfriendly techniques for those who consistently find it difficult, for whatever reasons, to use contraceptive methods that require some planning, organisation and forethought, like the pill, or even the brief deferment of gratification, like barrier methods. First came the intra-uterine contraceptive device; later, long-acting progestogen injections and various 'morning-after' compounds. For those not intending to have more children, there are several techniques for female or male sterilisation.

In FP clinics, some patients reject these medicosurgical methods. Apart from a relatively small number of people with strong religious feelings against any sort of fertility control, or against separating the pleasurable from the procreative aspects of sex, there are many non-religious people who dislike the idea of doctors interfering with their hormones or putting plastic devices into their wombs. Others dislike having their Fallopian tubes or spermatic ducts ligated. For these people, methods of HR based on a better understanding of the fertile and infertile phases of the menstrual cycle are available.

In a typical FP clinic, all of these methods coexist peacefully. The job of the staff is to show and if necessary explain the therapeutic menu and help patients to make an informed choice, though patients often have a good idea of the HR method that will best match their needs and do not necessarily require much help in making their choice. Even if FP clinicians think that a patient's preference is not ideal, they will not usually oppose the patient's choice unless there are very clear medical or psychosocial contraindications, which most 
dicaciones médicas o psicosociales que la mayoría de los pacientes tendrá la sensatez de admitir. Además, si un método resulta ineficaz o es eficaz pero provoca efectos secundarios inaceptables, el personal de PF siempre estará dispuesto a buscar alternativas.

Muchas veces ofrecen también orientación. Naturalmente, nadie se opone a que en los servicios de PF se ofrezca orientación e intervenciones psicológicas más concretas. Sin embargo, la orientación se considera menos importante que la reducción del riesgo de embarazos no deseados a través de las técnicas contraceptivas eficaces e inmediatas que se presentan a las pacientes y/o a sus parejas. Incluso cuando existen problemas psicosociales, el personal de PF no niega a las pacientes la contracepción hasta que se reduzcan dichos problemas con métodos psicosociales ni condiciona la contracepción a la aceptación de la orientación.

Por último, aunque la PF conlleva importantes consideraciones morales y éticas, aparte de las médicas, los debates se desarrollan en un ambiente imparcial. Los papeles de los médicos, las enfermeras y los asesores de PF son intercambiables, y todos coinciden en tener buena información sobre las intervenciones disponibles. El personal no médico debe recurrir en ocasiones a la experiencia médica, pero la preparación de dicho personal garantiza que todos comparten y utilizan en mismo cuerpo de información médica. Todo esto contrasta abiertamente con el ambiente de muchas clínicas de adicciones.

\section{Explicación}

Indudablemente uno de los motivos de este contraste es la influencia de Alcohólicos Anónimos (AA) y su organización hermana Narcóticos Anónimos (NA). Descrito a veces como "Modelo de Minnesota» o tratamiento en "doce pasos», este movimiento sigue dominando la ideología de los tratamientos en Estados Unidos. Se ha dicho que el movimiento de los doce pasos parece un culto religioso más que un programa de tratamiento de base científica, y varias sentencias recientes de los tribunales estadounidenses han prohibido a los programas de tratamiento financiados por los estados participar en las reuniones obligatorias de los doce pasos alegando que violan la separación constitucional entre Iglesia y Estado ${ }^{10}$. Curiosamente, uno de los cofundadores de AA, el famoso «Dr. Bob» se mostró tolerante con enfoques distintos a los de AA y respetó a sus colegas médicos. (Tal vez en parte porque, aparte de abstenerse de consumir alcohol, precisaba atención médica debido a un enfisema provocado por su adicción al tabaco, que fue el que acabó con su vida). Una importante publicación de AA afirma: "Tomar o no tomar disulfiram, hacer psicoterapia... Son decisiones vuestras. Respetamos vuestro patients are sensible enough to recognise. Furthermore, if one method proves ineffective, or is effective but causes unacceptable side effects, FP staff will always be happy to discuss alternatives.

Quite often, they will also offer some sort of counselling. Certainly, nobody argues that counselling and more specific psychological interventions have no place in FP services. However, counselling is usually seen as less important than reducing the risk of unwelcome pregnancy by immediately offering effective contraceptive techniques to patients and/or their partners. Even when psychosocial problems are prominent, FP staff do not suggest that patients should be denied contraception until these problems have been reduced by psychological methods; or that contraception should be refused if they decline to accept counselling.

Finally, although FP may involve important moral and ethical considerations as well as medical ones, discussions are usually carried on in a fairly non-partisan atmosphere. The roles of FP doctors, FP nurses and FP counsellors are often interchangeable but all of them are usually well informed about the various interventions that are available. Non-medical staff may sometimes need to defer to medical expertise but the training of FP staff normally ensures that everyone shares and uses the same large body of medical information. All this is in marked contrast to the atmosphere in many addiction clinics.

\section{Explaining}

Undoubtedly one reason for this contrast is the influence of Alcoholics Anonymous (AA) and its sisterorganisation Narcotics Anonymous (NA). Sometimes also described as 'Minnesota Model' or '12-Step' treatment, this movement is still the dominant treatment ideology in the United States. It has been argued that the 12-Step movement resembles a religious cult more than a scientifically based treatment programme and several recent judgements of US courts have forbidden state-funded treatment programmes to make participation in 12-Step meetings mandatory, on the grounds that this violates the constitutional churchstate separation. ${ }^{10}$ Ironically, one of the co-founders of AA, the famous 'Dr Bob', was tolerant of non-AA approaches and respected his fellow physicians. (Perhaps in part because although abstaining from alcohol, he needed medical attention for the emphysema, caused by his addiction to tobacco, which eventually killed him.) One important AA publication states 'To take or not to take disulfiram, to go into psychotherapy...These are all your own decisions. We respect 
derecho a elegir». Aunque para AA la consideración de la adicción como "enfermedad» constituye un artículo de fe, tanto AA como NA se han mostrado muy hostiles con el disulfiram y la naltrexona, por no mencionar la metadona.

El limitado repertorio terapéutico de las clínicas residenciales no es secreto. Muchas surgen abiertamente de una base ideológica exclusiva (generalmente los doce pasos, pero otras son religiosas o de la «Nueva Era») que rechaza, no sólo las teorías farmacológicas, sino también las psicológicas de la competencia. Sin embargo, también hay posturas antifarmacológicas en el tratamiento de las adicciones dentro de los servicios de pacientes externos, incluso con significativa participación médica. Esta rigidez ideológica en los servicios de adicciones se nota especialmente en Estados Unidos. Tal vez las actitudes cambien, pero un reciente estudio demuestra que menos del $15 \%$ de los pacientes de los médicos que tratan adicciones recibieron fármacos como la naltrexona o el disulfiram para el alcoholismo ${ }^{12}$. Los únicos casos equivalentes en PF (al menos en Occidente) son el reducido número de servicios de índole religiosa que ofrecen sólo técnicas basadas en la identificación del «período seguro».

\section{Consejo y otras intervenciones psicosociales}

Otro factor es la tradición psicoanalítica y la búsqueda de los "problemas subyacentes». Muchos consejeros, trabajadores sociales y psicoterapeutas, influidos por los conceptos psicodinámicos, creen que la adicción es habitualmente, y no sólo en ocasiones, una manifestación de problemas subyacentes o de conflictos neuróticos. En contraste con la postura de las clínicas de PF, se presupone que es más importante resolver los supuestos problemas subyacentes que combatir directamente el consumo de alcohol o de heroína. Gran parte de la "depresión» asociada al consumo de alcohol es una consecuencia y no una causa del consumo y lo mismo se puede decir del consumo de heroína ${ }^{13}, 14,15$. Sin embargo, los psicoanalistas sostienen que el mero ataque de "síntomas" tan evidentes como el consumo excesivo conduce a la "sustitución de síntomas». En realidad, los estudios controlados de la psicoterapia cognitivo-conductual en otros contextos indican que dichos temores carecen de fundamento ${ }^{16}$.

Una razón añadida es que, aunque la mayoría de las clínicas de PF cuentan con orientadores, los orientadores están subordinados a personal con conocimientos médicos y farmacológicos. En muchas clínicas de adicciones los psicólogos y los consejeros han ocupado tradicionalmente cargos de responsabilidad y, comprensiblemente, no quieren perder su estatus ni sus privilegios. En realidad, los médicos y las enfermeras pueden actuar a la vez (y suelen hacerlo) your right to make them.',"11 Yet although it is an article of the AA faith that addiction is a 'disease', AA/NA have generally been very hostile to disulfiram and naltrexone, not to mention methadone.

The limited therapeutic repertoire of residential clinics is not usually concealed. Many are overtly constructed around an exclusive ideological core (usually 12-step but sometimes religious or 'New Age') which rejects not just pharmacology but quite often competing psychological theories as well. However, antipharmacological attitudes in addiction treatment can be prominent in out-patient services, even when there is significant medical involvement. Such ideological inflexibility in addiction services is particularly evident in the US. Attitudes may be changing but a recent survey showed that fewer than $15 \%$ of the patients of addiction physicians received drugs such as naltrexone or disulfiram for alcoholism ${ }^{12}$. The only FP equivalents (at least in the West) are the small number of religiously-based services that offer only techniques based on identifying the 'safe period'.

\section{Counselling and other psycho-social interventions}

Another factor is the psychoanalytic tradition and the search for 'underlying problems'. Still heavily influenced by psychodynamic concepts, many counsellors, social workers and psychotherapists apparently believe that addiction is not just sometimes but usually a manifestation of underlying problems or neurotic conflicts. In contrast to the attitude in FP clinics, it is often implied that it is more important to resolve the alleged underlying problems than to attack alcohol or heroin use directly. Much of the 'depression' associated with alcohol abuse is actually a consequence rather than a cause of the drinking and the same almost certainly applies to heroin abuse. ${ }^{13,14,15}$ Nevertheless, psychoanalysts often assert that simply and crudely attacking such obvious 'symptoms' as heavy drinking will lead to 'symptom substitution'. In reality, controlled studies of cognitive-behavioural psychotherapy in other contexts indicate that such fears are generally groundless ${ }^{16}$.

An associated reason may be that while most FP clinics employ counsellors, the counsellors are subordinate to employees with medical and pharmacological expertise. In many addiction clinics, psychologists and counsellors have traditionally occupied senior roles and may be understandably reluctant to lose their status and privileges. After all, doctors and nurses can (and frequently do) double as counsellors and psychotherapists but psychologists cannot usually do 
como consejeros y psicoterapeutas, pero los psicólogos no pueden realizar exámenes vaginales. (Como observó Mark Twain, si tu única herramienta es un martillo, todos tus problemas te parecen tornillos). Si bien nadie duda de la utilidad (dejando a un lado la cortesía elemental) de ofrecer apoyo psicosocial a los pacientes, en las clínicas de adicción se tiende a negar intervenciones médicas a los pacientes que se resisten a hablar o escuchar o son demasiado tímidos para hacerlo. Esta actitud de «lo tomas o lo dejas» es muy rara en los centros de PF, donde la medicación efectiva sin consejo se considera preferible al consejo sin medicación efectiva.

\section{Consideraciones políticas}

Entre los descontentos con ciertos métodos médicos de RD están los miembros de los gobiernos, ministros y comités que dictan y promulgan las leyes que regulan el tratamiento de la adicción a las sustancias ilegales. Por ejemplo en Rusia, un país con graves problemas de heroína y de infección por $\mathrm{VIH}$, los programas de sustitución con agonistas siguen siendo ilegales (en enero de 2008). Y aunque el TMM se estudió por primera vez en Estados Unidos, hay todavía muy pocos centros de tratamiento y demasiadas barreras y reglas que limitan el acceso al tratamiento efectivo y la retención en el mismo. A pesar de la abrumadora evidencia de que las dosis altas de metadona dan mejores resultados que las bajas, muchos programas aplican dosis máximas de 80 mgs. o menos y ofrecen dosis medias muy inferiores. En Inglaterra, el TMM se convirtió en habitual, aunque mal organizado, a finales de los años sesenta y principios de los setenta, pero perdió el apoyo oficial en los años ochenta, si bien nunca fue declarado ilegal. Sí hubo una reducción obligatoria de las dosis. El TMM no volvió a ser una política oficial firme hasta 1999 y las dosis medias diarias oscilan entre 35 y 45 mg. ${ }^{17,18}$. Por contraste, semejante oposición fundamental a técnicas médicas importantes de PF es muy rara, incluso en las teocracias.

Los pacientes aceptan muy bien el TMM, que tiene efectos beneficios sobre la mayoría de los índices de daño relacionado con opiáceos, pero una sorprendente proporción de pacientes afirma que prefieren tratamientos que les permitan prescindir de los opiáceos ${ }^{19}$. Por desgracia, los porcentajes convencionales de éxito tanto en el abandono de los opiáceos como en la duración de los períodos de abstinencia son bajos ${ }^{20}$, sobre todo (en ambos casos) porque los métodos que se ofrecen habitualmente son subóptimos y desagradables para el paciente. Los porcentajes de iniciación en la NTX oral para prevenir recaídas ${ }^{21}$ son muy bajos. Frente a ello, los especialistas en PF han admitido hace mucho tiempo que las intervenciones teóricamente efectivas pero que exigen demasiado a los pacientes (o vaginal examinations. (As Mark Twain observed, if your only tool is a hammer, all your problems look like nails.) Furthermore, while nobody doubts the potential usefulness (not to mention the simple courtesy) of offering psycho-social support to patients, there is a tendency in addiction clinics to deny medical interventions to patients who are not impressed with talking and listening, or are too inhibited to contemplate it. Such take-it-or-leave-it attitudes are very unusual in FP settings, where effective medication without counselling is generally regarded as better than counselling without effective medication.

\section{Political considerations}

Among those who may be unhappy with some medical methods of HR are members of governments, ministries and committees that make and enforce laws regulating the management of addiction to illicit drugs. For example, in Russia, a country with serious problems of both heroin and HIV infection, agonist substitution programmes are still illegal (as of January 2008). And although MMT was first studied in the USA, there are still too few treatment slots and too many barriers and regulations that can limit access to, and retention in, effective treatment. Despite overwhelming evidence that higher rather than lower methadone doses give better results, many programmes still operate irrational upper dose limits of 80mg or less and offer average doses that are far too low. In Britain, MMT was routine, if poorly-organised, in the late 1960s and early 1970s but lost official favour by the 1980s, though it was never illegal. Forced dose reductions became usual. MMT only became firm official policy again in 1999 and average daily doses are still commonly in the 35-45mg range ${ }^{17,18}$. In contrast, such fundamental political opposition to important medical techniques in FP is uncommon, even in theocracies.

MMT is widely accepted by patients and has useful effects on most indices of opiate-related harm but a surprising proportion of patients claim they are interested in treatments aimed at increasing their chances of becoming and remaining opiate-free. ${ }^{19}$ Unfortunately, conventional success rates for both opiate withdrawal and worthwhile periods of abstinence are low, ${ }^{20}$ mainly (in both cases) because the methods commonly offered are both sub-optimal and user-unfriendly. Induction rates onto oral NTX for relapse-prevention ${ }^{21}$ are often very low. In contrast, FP clinicians have long recognised that interventions which are theoretically effective but make unreasonable demands on patients (or doctors) are not much use in real life. The emerging addiction equivalents 
a los médicos) no tienen gran aplicación en la vida real. Para las adicciones existen soluciones equivalentes a las técnicas de PF asequibles a los usuarios, como varias preparaciones de naltrexona en depot de larga duración o en implantes; algunas ya se han autorizado; hay también vacunas de larga duración o anticuerpos monoclonales (a punto de ser comercializados) para el tratamiento del consumo de nicotina, cocaína, fenciclidina y otras drogas. Las técnicas humanas de abandono de los opiáceos que utilizan diferentes niveles de sedación en varias etapas evitan el malestar y la fobia específica al abandono de la sustancia que disuaden a muchos pacientes de la desintoxicación, sobre todo después de malas experiencias previas ${ }^{22}$. Sin embargo, en Grecia se considera delito utilizar la sedación durante un abandono precipitado de la adicción.

\section{Flexibilidad}

Las clínicas de PF saben que hay grandes diferencias entre las personas que buscan $\mathrm{RD}$ procreador, tanto en la frecuencia como en el contexto de su actividad sexual. Es famoso el caso de uno de los informantes de Kinsey que declaró mantener relaciones sexuales 27 veces por semana, mientras que en el otro extremo de la escala hay personas cuya actividad sexual está separada por semanas o meses de abstinencia. Las clínicas de PF tienen en cuenta estas diferencias. Por desgracia, numerosas clínicas de adicciones ignoran por sistema las diferencias que existen en los modelos y contextos de consumo de sustancias. Sin embargo, muchos pacientes conocen bien el alcance de las intervenciones, sus ventajas y sus desventajas, como los pacientes de las clínicas de PF. Cuando se les presentan opciones, suelen elegir con sensatez. Mi experiencia personal en una clínica que ofrece tanto mantenimiento con agonistas como tratamiento con NTX oral o implantada es que ambas posibilidades gozan de aceptación y que los pacientes eligen con fundamento. Algunos proveedores de TMM consideran la NTX como una amenaza más que como una alternativa; sin embargo, en Australia hay políticos e incluso médicos que han utilizado la existencia de la NTX (sobre todo las preparaciones en depot/implantes) como argumento contra el mantenimiento con agonistas. Esas guerras por el control son prácticamente desconocidas en PF.

\section{CONCLUSIÓN}

Como las adicciones, la PF presenta importantes aspectos morales y legales, pero en ella ha existido desde hace tiempo un amplio consenso acerca del tipo de intervenciones que se ofrecen. Los servicios de PF de todo el mundo, sean públicos o privados, to user-friendly FP techniques are various long-acting depot or implanted naltrexone preparations, some of which are now licensed, and long-acting vaccines or monoclonal antibodies (some of them very near commercial availability) aimed at nicotine, cocaine, phencyclidine and other drugs of abuse. Humane techniques of opiate withdrawal, using various levels of sedation for various periods, can largely remove the distress and specific withdrawal phobia that deters many patients from considering detoxification, especially after previous bad experiences ${ }^{22}$. However, in Greece, it can apparently be a criminal offence to use sedation during precipitated withdrawal.

\section{Flexibility}

FP clinics know that their clients vary enormously in frequency and context of sexual activity. One of Kinsey's informants famously reported averaging 27 times/week, while at the other end of the scale are people whose episodes of sexual activity may be typically separated by weeks or months. FP clinics routinely take these differences into account. Unfortunately, many addiction clinics equally routinely ignore equivalent differences involving patterns and contexts of substance use. Yet many of their patients are as wellinformed about the range of interventions, and their advantages and disadvantages, as are the patients of FP clinics. When presented with choices, they often consider them sensibly. Certainly, my own experience in a clinic that offers both agonist maintenance and treatment with oral or implanted NTX is that both are popular and are usually selected by patients on appropriate grounds. Yet some MMT providers seem to regard NTX as a threat rather than an alternative, while in Australia, some politicians and even a few physicians have used the existence of NTX (especially depot/implanted preparations) as an argument against agonist maintenance. Such 'turf wars' are almost unknown in FP.

\section{CONCLUSION}

Like addiction, FP has major moral and even legal dimensions but a broad consensus has long existed on the range of interventions that should be offered. Throughout the world, FP services, whether public or private, have much in common and differ mainly 
tienen mucho en común y se diferencian principalmente en los niveles de financiación. Cuesta superar la sensación de que en muchos países el tratamiento de las adicciones está muy influenciado por la rigidez moral, ideológica y conceptual que existió antes en la PF y que hace tiempo ha dejado paso a una actitud en general flexible, sin prejuicios, favorable al paciente y utilitaria. Muchos servicios de adicción se beneficiarían de la transfusión de estas características.

\section{REFERENCIAS / REFERENCES}

1. Brewer C. Psychological and pharmacological components of treatment: conflict or co-operation? En: Eds: Philip Bean, Theresa Nemitz. Drug Treatment. What works? London: Routledge; 2004.

2. Bale RN, Van Stone WW, Kuldau JM, Engelsing TM, Elashoff RM, Zarcone VP Jr. Therapeutic communities vs methadone maintenance. A prospective controlled study of narcotic addiction treatment: design and oneyear follow-up. Arch Gen Psychiat 1980; 37: 179-93.

3. Keen J, Oliver P, Rowse G, Mathers N. Residential rehabilitation for drug users: a review of 13 months' intake to a therapeutic community. Fam Pract 2001: 16; 545-548.

4. Berglund $M$, Thelander S, Salaspuro M, Franck J, Andréasson S, Öjehagen A. Treatment of Alcohol Abuse: An Evidence-Based Review. Alc: Clin Exper Res 2003, 27: 1645-1656.

5. Cornish J, Metzger, D, Woody, G, Wilson, D, Mclellan, T, Vandergrift, B, O'brien, C, 1997. Naltrexone pharmacotherapy for opioid dependent federal probationers. J Subst Abuse Treat. 14, 529-34.

6. Chan KY. The Singapore naltrexone community-based project for heroin addicts compared with drugfree community-based program: the first cohort. J Clin Med 1996; 3: 87-92.

7. Cornish JW, Metzger D, Woody GE, Wilson D, McLellan AT, Vandergrift B, O'Brien CP. Naltrexone pharmacotherapy for opioid dependent federal probationers. J Subs Abuse Treat 1997; 14: 529-534.

8. Brewer C. Third time unlucky: a study of women who have three or more legal abortions. J Biosoc Sci 1977; 9: 99-105.

9. Luker K. Taking Chances. Los Angeles: Univ. of California Press; 1975.

10. Decision of NY Court of Appeals, 11 June 1996, Griffin vs Coughlin.

11. Alcoholics Anonymous. Living Sober. London: Jupiter; 1975. p. 60.

12. Mark TL, Kranzler HR, Song X, Bransberger P, Poole V, Crosse S. Physicians' opinions about medications to treat alcoholism. Addiction 2003; 98: 617-26. in levels of funding. It is difficult to avoid the feeling that addiction treatment in many countries remains heavily influenced by the sort of moral, ideological and conceptual rigidity that used to be common in FP but has long been abandoned there in favour of a generally flexible, patient-friendly and utilitarian ethos. Many addiction services might benefit from a transfusion of these characteristics.

13. Shuckit MA. Alcohol and depression: a clinical perspective. Acta Psych Scand. Suppl 1994; 377, 28-32.

14. Davidson K. Diagnosis of depression in alcohol dependence: changes in prevalence with drinking status. Br J Psychiat 1993; 166: 199-204.

15. Mclntosh C, Ritson B. Treating depression complicated by substance misuse. Advances in Psychiatric Treatment 2001; 7: 357-364.

16. Gelder MG, Marks I, Wolff HH. Desensitisation and psychotherapy in the treatment of phobic states: a controlled clinical enquiry. Brit J Psychiat 1967; 113: 53-73.

17. Strang J. Sheridan J, Hunt C, Kerr B, Gerada C, Pringle $M$. The prescribing of methadone and other opioids to addicts: national survey of GPs in England and Wales Br J Gen Pract 2005; 55: 444-51.

18. Strang J, Manning V, Mayet S, Ridge G, Best D, Sheridan $J$ Does prescribing for opiate addiction change after national guidelines? Methadone and buprenorphine prescribing to opiate addicts by general practitioners and hospital doctors in England, 1995-2005. Addiction 2007; 102: 761-70.

19. McKeganey N, Morris Z, Neale J, Robertson M. What are drug users looking for when they contact drug services: abstinence or harm reduction? Drugs: Education, Prevention and Policy 2004; 11; 423-35.

20. Strang J, McCambridge J, Best D, Beswick T, Bearn J, Rees S, Gossop M. Loss of tolerance and overdose mortality after inpatient opiate detoxification: follow up study. BMJ 2003; 326, 959-60.

21. Arnold-Reed DE, Hulse GK. A comparison of rapid (opioid) detoxification with clonidine-assisted detoxification for heroin-dependent persons. J Opioid Manag 2005; 1:17-23.

22. Seoane $A$, Carrasco G, Cabré $L$, Puiggrós $A$, Hernández E, Alvarez M, Costa J, Molina R, Sobrepere G. Efficacy and safety of two new methods of rapid intravenous detoxification in heroin addicts previously treated without success. Br J Psychiat 1997; 171: 340-5. 
